\title{
Perceptions of Students towards the Postgraduate Biology Practical Demonstrators at Sefako Makgatho Health Sciences University, Pretoria, South Africa
}

\author{
Liziwe L. Mugivhisa \\ https:/ / orcid.org/0000-0002-6112-5478 \\ Caswell Mavimbela \\ https://orcid.org/0000-0001-5754-439X \\ Joshua O. Olowoyo \\ https:/ / orcid.org/0000-0001-8601-091X
}

\begin{abstract}
The present study assessed the experiences of junior students on the ability, performance, and competence of demonstrators or instructors for practical classes in the Biology department. A total of 148 self-administered questionnaires were completed by the junior Biology students in years 1,2 , and 3 . The result showed that $52.1 \%$ and $62.3 \%$ of the participants indicated that the demonstrators had adequate content knowledge of the practical sessions and were helpful during practical sessions respectively. Furthermore, 51.4\% agreed that the marking of the practical assessments by the demonstrators was not usually accurate. Most of the respondents stated that the demonstrators were good listeners $(77.4 \%)$, approachable $(71.9 \%)$ and $83.0 \%$ of the participants did not have any problems with taking instructions from the demonstrators. The majority $(69.0 \%)$ of the participants wanted the services of the demonstrators to be continued and $36.0 \%$ felt that there was a need to increase the number of demonstrators for the practical sessions. Some of the shortcomings of the demonstrators as mentioned by the respondents were the use of cell phones during the practical sessions and that the demonstrators were fond of talking amongst themselves rather than concentrating on the students they were supposed to assist. In general, though the demonstrators were considered to be helpful and that their services should be continued it is however recommended that they should be required to write pre-practical tests before the practical classes to improve their competency in marking and giving accurate answers during the practical classes.
\end{abstract}

Keywords: Demonstrators; Practical Classes; Laboratory; Postgraduate Students 


\section{Introduction}

The large numbers of undergraduate students enrolled at universities together with the decrease in the public funding has resulted in postgraduates or senior students being employed on a part-time basis to assist with the running of undergraduate classes at institutions of higher learning (Flaherty et al., 2017). This has assisted with addressing the challenges of high numbers of students even though there is a low teacher-to-student ratio (Durán et al., 2012). The first-year class consists of a group of students with diverse backgrounds and academic abilities, hence, it becomes more difficult to coordinate activities that encourage the application of concepts outside the lecture such as laboratories (Sana et al., 2011). Due to the large classes, one lecturer cannot conduct the laboratories and lectures resulting in an introduction of having postgraduate or senior students to lead the laboratory sessions which make up a major component of the classes in the sciences (Chapin et al., 2014). According to Felege, (2018), the use of teaching assistants who are graduates for several teaching duties has been practiced at most tertiary institutions.

For the majority of the institutions of higher education, there has been more reliance on the employment of the graduate teaching assistants who can also be referred to as demonstrators. Big universities in the United States depend on graduate students and teaching assistants for teaching the laboratory sessions in the sciences especially at the introductory levels of subjects such as Biology (Basey et al., 2014; Schussler et al., 2015). These graduate teaching assistants have been found to play an important role in the standard of the education of the undergraduates and to have an impact on the understanding of the undergraduates when it comes to the comprehension of inquiry-based chemical concepts in the laboratories (Wheeler et al., 2015). The graduate teaching assistants who are in the practice of integrating their overlapping roles of being teachers and students have an impact on the learning of the students (Spike, 2016). The postgraduates have also been used as teaching assistants in other fields such as Medicine in the majority of the medical schools in the United States (Lachman et al., 2013).

Even though these graduate students usually have minimum formal teacher training or preparation, they should be considered as partners who have an impact on the influence and support of the learning and education of the students (Spike, 2014). According to Chiu and Corrigan (2019), from the 1990s, most managers at the universities have started to realise the significance of having graduate teaching assistants who are properly trained so that they are able to provide high-quality support and assistance to the undergraduates and as a result, there have been efforts made to invest in the training of these graduate assistants.

The graduate students are used as teaching assistants with responsibilities ranging from managing laboratory sessions to assessing students in Science Technology Engineering and Mathematics (STEM) fields (Weidert et al., 2012). However, few studies have been done to assess the impact of the demonstrators on the teaching of the undergraduates (Kendall and Schussler, 2013). In addition 
to their roles as facilitators, graduate teaching assistants in the laboratories are responsible for marking, giving feedback, setting up materials/types of equipment, motivating and encouraging students, presenting experimental techniques and pre-laboratory lectures, and assisting students in scientific practices (Wheeler et al., 2015).

According to Lama and Joullie (2015), at most Australian universities, enrolments of students increased when there was a greater emphasis on doing research resulting in less involvement of academic staff who were employed on a full-time basis in teaching. As a result, there was a need for demonstrators to offer support for the learning of the students in the science laboratories. The support of the learning process for the undergraduate students during the practical sessions is largely dependent on the demonstrators who have a substantial impact on the experiences of the undergraduate students in the laboratories (Kirkup et al., 2016).

Only through the work that is carried out in the laboratories, can the practical work in science education be guaranteed (Gudyanga \& Jita, 2019). Leaners acquire actual experiences of the natural world in the laboratories. When improvements are done globally with respect to the science curriculum, changes also have to be considered when it comes to the large-scale components of the practicals including how experimental work is conducted by the students (Gudyanga \& Jita, 2019). According to Russell and Weaver (2008), there is a belief that within science education there is a coalition of practice and theory in the laboratories. Taking part in proper research in a laboratory for an undergraduate who wants to pursue a career in the scientific research seems like a noble opportunity (Linn et al., 2015; Bowling et al., 2015; Bangera \& Brownell, 2014). According to a survey by Linn et al., (2015) at 200 institutions, undergraduates appreciated the research experiences which they gained in the laboratories.

Laboratory sessions play a role of being the core element of the courses in the sciences and they are for the development of experimental skills and sometimes even being for emphasizing the theoretical concepts and principles (Braun \& Kirkup, 2016; Gardner \& Jones, 2011). The hands-on activities which take place in the laboratories are considered to be essential for science degrees (Hofstein \& Lunetta, 2004). According to Wilson et al., (2011), experiences that undergraduates can gain in conducting research in the laboratories have been associated with improvement of the educational experiences of the undergraduates and increased retention rates of the graduates. Also, there is an enhancement of the skills in research and increased perseverance to the undergraduate degree and selection of a career in STEM when students engage in research in the laboratories.

According to DeBeck and Demaree (2012), in most cases, teaching assistants play roles as the primary contact for the students and as a mediator between the students and the professors. As a result, demonstrators end up interacting directly more with the students. When demonstrators are given contracts by university management, it is usually for the whole year meaning that the undergraduates may be in contact with the same demonstrators for the whole year. As a result, the contact that the demonstrator has with the students becomes 2 to 3 times more 
than the time the student would spend with any other academic member of staff (Braun \& Kirkup, 2016; Gardner \& Jones, 2011). In the laboratories, the undergraduate students are more exposed to one-on-one experiences with the demonstrators compared to when they are in with lecturers (French \& Russell, 2002).

In the large lectures, students do not usually get a chance to interact with the content of the lecture actively or get a chance to ask questions because they may feel frightened to participate in such big groups and to also interact with the lecturers which they might not be familiar with (Drane et al., 2014). Besides, lecture classes are much bigger than the laboratory sessions pointing towards the importance of the role of demonstrators in the learning of science (French \& Russell, 2002).

Interactions between demonstrators and students which are effective can contribute to the success of the laboratory sessions through students' engagement with the products and processes of science in the laboratories (Kirkup et al., 2016). The positions of teaching assistants are usually associated with esteem, respect, power, and authority in the undergraduate laboratories and classrooms (Chapin et al., 2014). Usually, these positions are given to academically sound postgraduate students. The experiences of the undergraduates are important in determining whether the students are retained in the sciences and have a good understanding of the subject content which they will use later in their professions (Kendall \& Schussler, 2013).

According to Flaherty et al., (2017), it has been stated in a national Australian report that the laboratory demonstrators are the most significant resources associated with the undergraduates' experiences as they know what is to be done in the laboratories and also how it should be done. Also, they set the tone of the learning environment for the undergraduates. In the study of Kirkup et al., (2016), demonstrators were seen as having powers to make a laboratory experience of the undergraduates either miserable or great. Irrespective of how important the demonstrators are, there has been little effort carried out in assessing the influence they have on the experiences of the students in the undergraduate laboratories where the main focus is on the experiments (Wyse et al., 2014). Few studies have also been done to assess the impact of the demonstrators on the teaching of the undergraduates (Kendall \& Schussler, 2013).

Due to the changes in the global economy, there has been an escalation in the demand for STEM professionals (Wilson et al., 2011). There is also a need for ways to reconceptualise STEM education at the tertiary level at the nation's universities and colleges because of an escalating need for professional engineers and scientists together with fears about the absence of commitment in science careers (Drane et al., 2014). However, below 50\% of the students who have enrolled in the STEM undergraduate curricula, will eventually graduate with a degree in STEM in the United States (Wilson et al., 2011). As a result, this can contribute to a decline of about one million science graduates from colleges in STEM over the coming decade (Graham et al., 213). Policy-makers and educators have stressed that there 
is a need for a shift in the STEM education from the model of traditional lectures to methods that encourage teaching based on research to enhance the learning of the students (Carlson et al., 2016).

Teaching assistants have been shown to play a crucial and fundamental role in the teaching of undergraduates in computer science (Patitsas, 2012). The performance of teaching assistants at twenty-three laboratories at the University of British Colombia in North America was found to be affected by aspects such as demonstrators getting support from the lecturers. In a large urban university at the United States research-intensive university, carefully chosen undergraduate teaching assistants were employed and supported to assist with supporting students in the general chemistry course for preliminary STEM majors so that the performance of the students could be enhanced (Phillipp et al., 2016b). In addition to other several studies in Phillipp et al., (2016b), the presence of the teaching assistants was found to correlate with the determination of the students to proceed to the next semester of the course irrespective of how the students had performed.

According to Felege (2018), research has shown that there is more engagement of the students with the demonstrators. Students tend to seek assistance from the teaching assistants because of the latter being less intimidating. This has also been shown to have several benefits related to the learning of the students. The teaching assistants are also considered to be more flexible, sociable, and casual by the students and this encourages the students to reach out and approach them instead of teaching staff. Students tend to approach the teaching assistants more for help and this contributes to a decrease in the demand and workload on the teaching staff (Kendall \& Schussler, 2012). However, according to Weidert et al., (2012), there is more workload put on teaching staff when teaching assistants are involved because they need to be trained, supervised and mentored and also time can also be spent on correction of mistakes made or addressing of confusion brought about by the teaching assistants.

In some universities such as where the present study was conducted, postgraduate students or undergraduate students who have good grades and are about to finish are usually employed as demonstrators to assist with practical classes. This assistance often comes with stipends that are paid to the demonstrators at the end of each month. To the best of our knowledge, no studies have been carried out to investigate the experience of the Biology students on the performance and competence of the practical demonstrators at most of the universities in South Africa although they are usually employed as part-time student assistants. Hence, the study aimed to assess the experiences of the Biology students on the performance and competence of the practical demonstrators in the Department of Biology in the School of Science and Technology at Sefako Makgatho Health Sciences University, Pretoria, South Africa.

\section{Materials and Methods}

The study was quantitative and involved completion of a total of 148 Selfadministered questionnaires (Appendix 1) consisting of open and close-ended 
questions by the Biology undergraduates to assess the effectiveness of the postgraduate students (Honours, Masters, and Ph.D.) who are laboratory demonstrators in the Biology department in the School of Science and Technology at Sefako Makgatho Health Sciences University (SMU) in the north of Pretoria. The study was purposive, based on voluntary participation and the willingness of the students to partake. Consent was first sought from the students before they could participate. The students were informed that their participation was purely voluntary, that they could withdraw from the study at any time, and that their unwillingness to participate in the study would not affect them in any negative way or disadvantage them. The questionnaires were distributed to the students during the afternoons which were scheduled for their practicals before the commencement of the practicals. This was done so that participants would not be inconvenienced in any way.

The postgraduates who were assessed by the participants were responsible for running the undergraduate Biology practical classes (years 1, 2, and 3) usually under the supervision of a staff member who provides instructions before the commencement of the practical classes and oversees the running of the entire practical sessions. The students who participated in the study were from Year 1 $(9.0 \%)$ Year $2(89.0 \%)$ and year $3(2.0 \%)$ with the age distribution of $16-20(50.0 \%)$, $21-24(47.0 \%)$ and $25-29(2.0 \%)$. The majority $(77.0 \%)$ of the participants were females with males only making up $21.0 \%$ of the participants while $2.0 \%$ of the respondents did not indicate their gender.

The practical classes are offered once a week for each level (years 1, 2, and 3) for a duration of three hours in the afternoons. The laboratory practical classes are done in conjunction with the content of what the undergraduates are taught in lectures. The practical marks form part of the formative assessment and count towards the final year marks of the students. In addition, there is also a practical exam written by undergraduates at the end of each semester. The information sought from the participants included the demographics (year of study, age, and gender). The main information which was sought was on the experiences of the undergraduates on demonstrators such as whether they felt the demonstrators were helpful during practical sessions, if the demonstrators had enough knowledge on the content of the practical sessions, if the demonstrators were well prepared for practical sessions and if they were fair in the assessment of their submitted work. Data was represented using frequency tables and graphs. An analysis of variance (ANOVA) was also used to assess if there was any significant difference between some of the responses of the students.

The current practice at the university (Sefako Makgatho Health Sciences University) is that postgraduates who assist in the laboratories are employed as students' assistants and are remunerated based on the number of hours they have worked. As a result, the postgraduate demonstrators value the work they do as it assists them financially during their postgraduate courses. All the postgraduates who assist in practical classes have a strong academic background in Biology as they have to score above a minimum of $60 \%$ for them to be admitted into the postgraduate level and be able to assist with practical sessions. 


\section{Results and Discussions}

The result as shown in Figure 1 indicate that more $(49.0 \%)$ participants indicated that the people who qualified to be demonstrators were the postgraduates while $39.0 \%$ of the participants felt that any senior student could work as a demonstrator at any level which is below his or her level. A high number $(12.0 \%)$ of the participants did not respond to a question on who qualifies to be a demonstrator. This challenge of the students choosing not to respond to some of the questions is the first shortfall of self-administered questionnaires in the study.

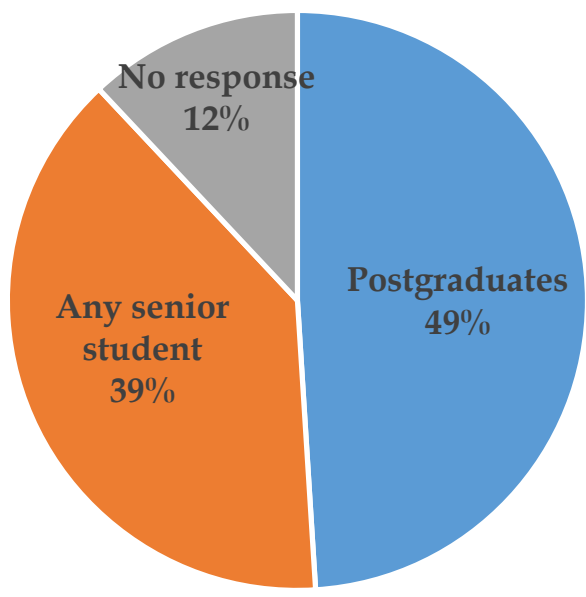

Figure 1. Responses of the participants on who qualifies to be a demonstrator.

Figure 2 shows that more of the participants felt that the demonstrators had adequate knowledge on the content material of the practical compared to the participants who felt that the demonstrators did not have adequate knowledge of the content material of the practical classes. These results are in agreement with those in Kirkup et al., (2016) and Tulane and Beckert (2011), where the demonstrators were found to be knowledgeable about the experiments in the laboratories. In Fernald et al., (1975), the mastery of content knowledge was one of the criteria which was used for the selection of undergraduate teaching assistants. However, about the knowledge on the content material, in Filz and Gurung (2013), knowledge on the content of the course was not seen as an important feature required for undergraduate teaching assistants.

Slightly more than half $(52.0 \%)$ of the respondents responded that demonstrators were prepared for the practical sessions was whereas $41.8 \%$ of the respondents responded that the demonstrators did not come to the practical classes prepared (Figure 2). The participants did not respond to the question on the preparedness of the demonstrators during practical classes was $6.2 \%$. These findings compare with the findings in Kirkup et al., (2016), where the demonstrators took time to prepare for experiments before going to the laboratory sessions. In BuerkelRothfuss et al., (1993), the participants felt that the teaching assistants were 
qualified, prepared, organized, responsible, and as interested in teaching as the lecturers.

The majority of the participants $(62.3 \%)$ as shown in Figure 2, indicated that the demonstrators were helpful compared to fewer participants $(32.2 \%)$ who indicated that the demonstrators were not helpful during the practical sessions while $5.5 \%$ of the participants did not indicate whether the demonstrators were helpful or not helpful. These results of the majority of the students finding the demonstrators helpful agree with those of Kirkup et al., (2016); He et al., (2018) and Braun et al., (2018) where the students stated that the demonstrators were helpful when it came to the explanations and demonstrations of the experiments in the laboratories. According to Filz and Gurung (2013), being helpful is one of the characteristics that demonstrators have to possess before they can be hired.

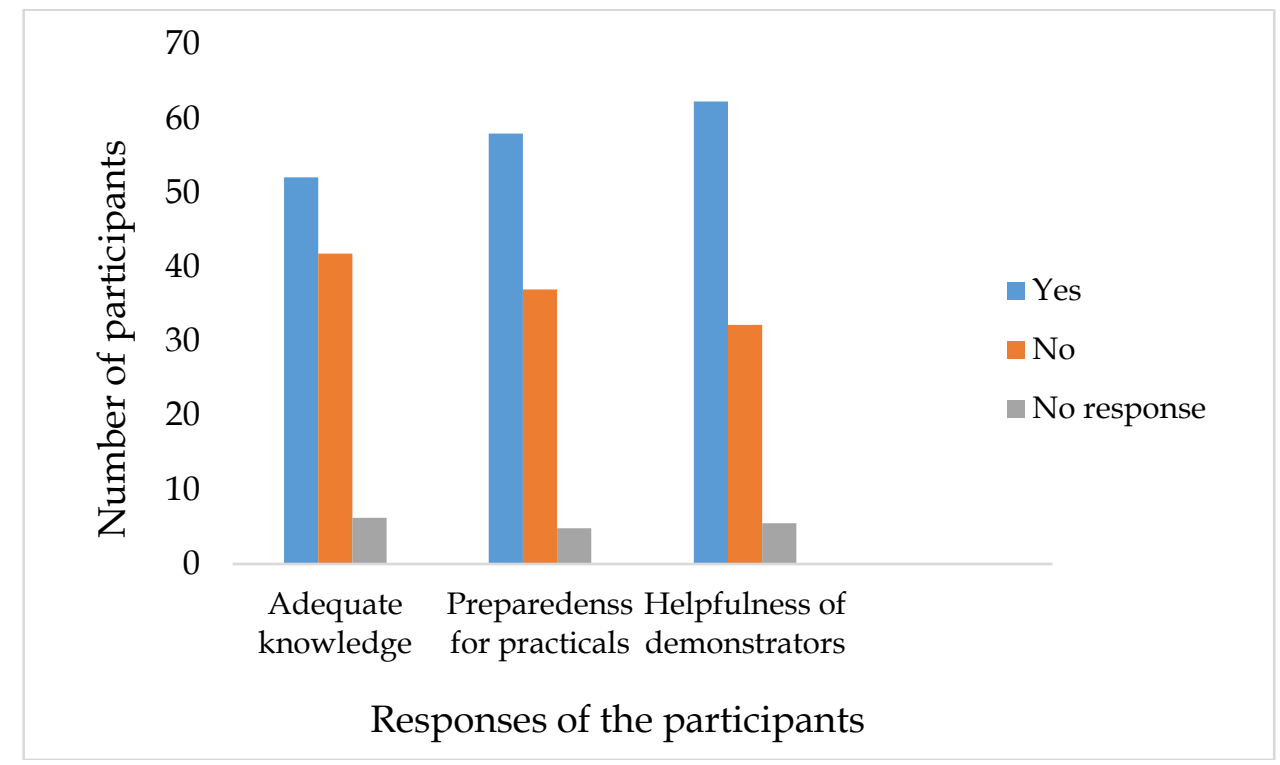

Figure 2. Responses on preparedness, helpfulness, and knowledge of demonstrators.

Participants who doubted the responses that the demonstrators gave on some of the aspects of the practical sessions made up $50.7 \%$ while $45.2 \%$ of the participants stated that they did not doubt the responses of the demonstrators on some aspects of the practical sessions and $4.1 \%$ of the participants did not respond to the question as shown in Table 1. These findings are not in agreement with those in He et al., (2018) where only $11.0 \%$ of the participants had stated that the teaching assistants had occasionally given them wrong information. In Brauna et al., (2018), $2.0 \%$ of the participants in the Chemistry class doubted the expertise of the demonstrators compared to $24.0 \%$ of the participant in the Physics class who doubted the knowledge of the demonstrators. In Philipp et al., (2016a), the majority $(90.0 \%)$ of the undergraduate teaching assistants had confidence in their knowledge of the content material and could provide answers to the questions raised by the students. The teaching assistants also felt that they contributed to the understanding of the students. 
According to Table 1,52.1\% and $43.8 \%$ of the participants understood the role of the demonstrators and did not understand what the role of the demonstrators was during the practical sessions respectively while $4.1 \%$ of the participants did not indicate if they understood or did not understand the role of the demonstrators. As a result, $13.0 \%$ of the participants had a problem with taking instructions from demonstrators during practical sessions with more (83.6\%) of the participants not having problems with taking instructions from the demonstrators. These findings in the present study are comparable to those in Braun et al., (2018) where 93.0\% and $76.0 \%$ of the participants in the Chemistry and Physics respectively acknowledged the important role that the demonstrators played in their learning process. According to Chapin et al., (2014), teaching assistants or demonstrators end up gaining skills in giving instructions and being confident.

A smaller $(28.1 \%)$ number of participants described the demonstrators as being impossible and hard to deal with compared to a much larger $(64.4 \%)$ number of participants who described demonstrators as not being impossible or hard to deal with during practical sessions with $7.5 \%$ not responding (Table 2). The majority $(61.0 \%)$ of the participants indicated that they would report the demonstrators to the seniors if they mistreated them compared to $32.9 \%$ of the participants who indicated that they would not report them while $6.2 \%$ of them did not indicate whether they would report or not report the demonstrators if they mistreated them.

With regards to the responses on whether the demonstrators can listen to the complaints or queries by the participants, $(115 / 148)$ participants felt that the demonstrators were able to listen to their complaints or queries while only (26/148) participants indicated that the demonstrators did not have the patience to listen to the complaints or queries with $(7 / 148)$ participants not responding. In McKeegan (1998), being patient and responsible were some of the traits which undergraduate teaching assistants had to possess. In Philipp et al., (2016), the undergraduate teaching assistants stated that it was important that teaching assistants had patience and willingness to understand that not all the students had the same background.

Most $(64.4 \%)$ of the participants felt that the demonstrators were fair and did not show any favouritism towards the students while $29.5 \%$ of the participants felt the demonstrators were not fair and showed favouritism towards some of the students while $6.2 \%$ did not respond to the question. In Buerkel-Rothfuss et al, (1993), the authors mentioned that the teaching assistants were softer when it came to grading compared to the staff members and that it was important to remind teaching assistants regularly to be objective and fair when grading the students' work. 
Table 1. Responses of the participants on the demonstrators.

\begin{tabular}{|l|c|c|c|}
\hline \multicolumn{1}{|c|}{ Responses } & Yes & No & $\begin{array}{c}\text { No } \\
\text { response }\end{array}$ \\
\hline $\begin{array}{l}\text { Do you doubt the knowledge/responses of the } \\
\text { demonstrators? }\end{array}$ & 50.7 & 45.2 & 4.1 \\
\hline $\begin{array}{l}\text { Do you understand the role of a demonstrator in a } \\
\text { practical? }\end{array}$ & 52.1 & 43.8 & 4.1 \\
\hline $\begin{array}{l}\text { Do you have any problems with taking instructions from } \\
\text { demonstrators? }\end{array}$ & 13.0 & 83.6 & 3.4 \\
\hline $\begin{array}{l}\text { Are the demonstrators difficult/impossible to work } \\
\text { with? }\end{array}$ & 28.1 & 64.4 & 7.5 \\
\hline $\begin{array}{l}\text { Are demonstrators able to listen to complaints/queries } \\
\text { by participants? }\end{array}$ & 77.4 & 17.8 & 4.8 \\
\hline
\end{tabular}

As shown in Figure 3, students believed that demonstrators could mark the practical reports even though most of the participants felt that the marking of the demonstrators was inaccurate. More participants had prior complaints on the marking of the demonstrators compared to those who had not complained about the marking of the demonstrators. The accuracy of the marking of the scripts by the demonstrators is crucial as the practical marks (weekly marks and practical exam) contribute towards the final mark of the students which qualify them for a pass or a fail in the Biology course. Inaccurate marking can give a false representation of the performance and the learning of the students.

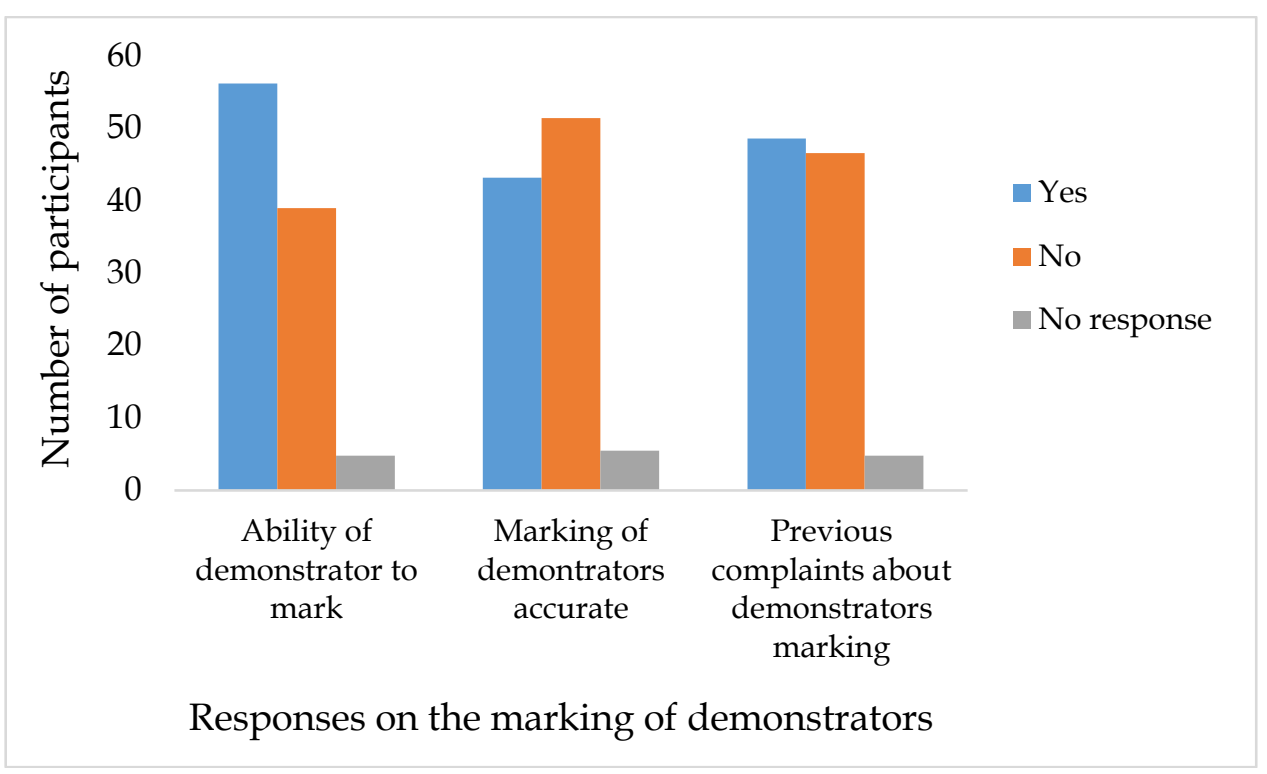

Figure 3. Responses of participants on the marking abilities of the demonstrators.

Figure 4 shows that the majority $(69.0 \%)$ of the participants felt that technical officers had a final say in what happens during practical sessions compared to only $23.0 \%$ of the participants who indicated that it was the lecturers who had a final say in what happens during the practical session whereas $8.0 \%$ of the participants did not respond on who should have a final say during practical sessions. 


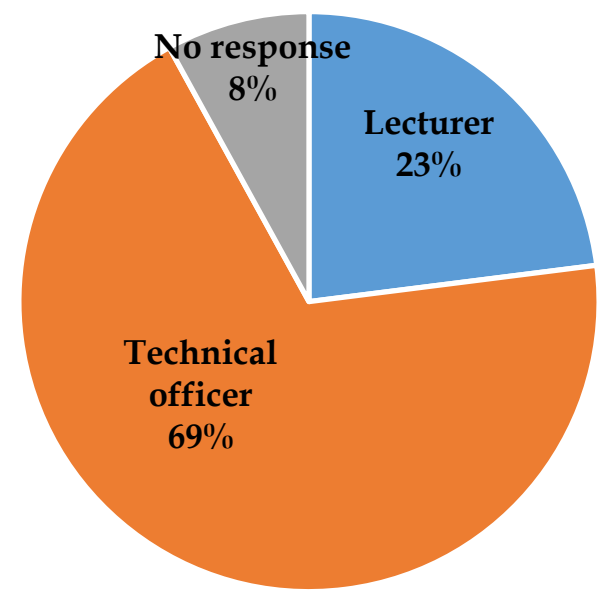

Figure 4. Responses on who has the final say in the case of disputes between demonstrators and students.

Table 2 shows that the majority $(71.9 \%)$ of the participants responded that the demonstrators were approachable when there were queries while the least $(11.6 \%)$ of the participants felt that the demonstrators were not approachable when there were queries. A high number $(16.4 \%)$ of participants did not respond to whether the demonstrators were approachable or not (Table 2). These findings agree with those in Braun et al., (2018) where the majority $(94.0 \%)$ and $(82.0 \%)$ of the participants in Chemistry and Physics classes respectively reported that the demonstrators were more approachable compared to lecturers. According to Gardner and Jones, (2011), the undergraduate students may find the postgraduate demonstrators more accessible and approachable compared to the lecturers because of the smaller differences between their social status and ages resulting in them consulting the demonstrators more than they would approach the lecturers.

In Buerkel-Rothfuss et al., (1993), the teaching assistants were considered to do well in teacher-student relationships such as being friendly and more willing to listen to alternative viewpoints of the students. However, in He et al., (2018) 2.0\% of the participants had stated that the teaching assistants were usually unavailable when they were needed. According to Chapin et al., (2014) and Gardner and Jones, (2011), the laboratory demonstrators have been rated by the undergraduates as being more engaging and approachable compared to the lecturers who are considered to be more boring and formal even though they are experts when it comes to content. According to Kendall and Schussler (2012), the teaching assistants are considered to be less intimidating compared to the lecturers even though they might not be as knowledgeable, experienced, and competent about the course content. As a result, students tend to think demonstrators are more approachable, understanding, and flexible. 
A significantly higher number of the participants indicated that the demonstrators did not use their cell phones during practical sessions or spoke amongst themselves when they were supposed to be assisting the students during the practical sessions $((p<0.05)$. The use of cell phones can be considered to be a distraction on the attention of the demonstrators on their effectiveness to run practical sessions and should hence be prohibited. The use of cell phones by the demonstrators could also be seen as a deterrent for the students to engage and interact with them. Quite a large number of participants $(11.0 \%$ and $10.7 \%)$ did not respond to whether the demonstrators spoke on their cell phones or amongst each other during the practical sessions.

A relatively higher number $(61 \%)$ of participants had reported the demonstrators to the seniors (lecturer or technical officer) if they were unhappy with their conduct or the way they treated them compared to only $32.9 \%$ who had never laid any complaints about the demonstrators. This could have been due to the participants being afraid of intimidation from the demonstrators if they reported them or maybe it could also be because they have not encountered unpleasant situations from the demonstrators.

Table 2. Participants' responses on the ability of the demonstrators to be competent and behave during practical sessions.

\begin{tabular}{|l|c|c|c|}
\hline \multicolumn{1}{|c|}{ Responses } & Yes & No & $\begin{array}{c}\text { No } \\
\text { response }\end{array}$ \\
\hline $\begin{array}{l}\text { Do you feel free to approach demonstrators in the } \\
\text { laboratory? }\end{array}$ & 71.9 & 11.6 & 16.4 \\
\hline $\begin{array}{l}\text { Do demonstrators talk amongst themselves and do not pay } \\
\text { attention to participants? }\end{array}$ & 38.4 & 50.7 & 11.0 \\
\hline $\begin{array}{l}\text { Do demonstrators use cell phones during practical sessions } \\
\text { instead of assisting participants? }\end{array}$ & 38.7 & 50.7 & 10.7 \\
\hline Do demonstrators show favouritism? & 64.4 & 29.5 & 6.2 \\
\hline $\begin{array}{l}\text { Have you ever reported a demonstrator if you were } \\
\text { unhappy? }\end{array}$ & 61.0 & 32.9 & 6.2 \\
\hline
\end{tabular}

Figure 5 shows that the order of the responses of the participants on the overall attitude of the demonstrators during practical sessions was "good" $(64.0 \%)>$ "excellent" $(16.0 \%)>$ no response $(11.0 \%)>$ "bad" $(9.0 \%)$. 


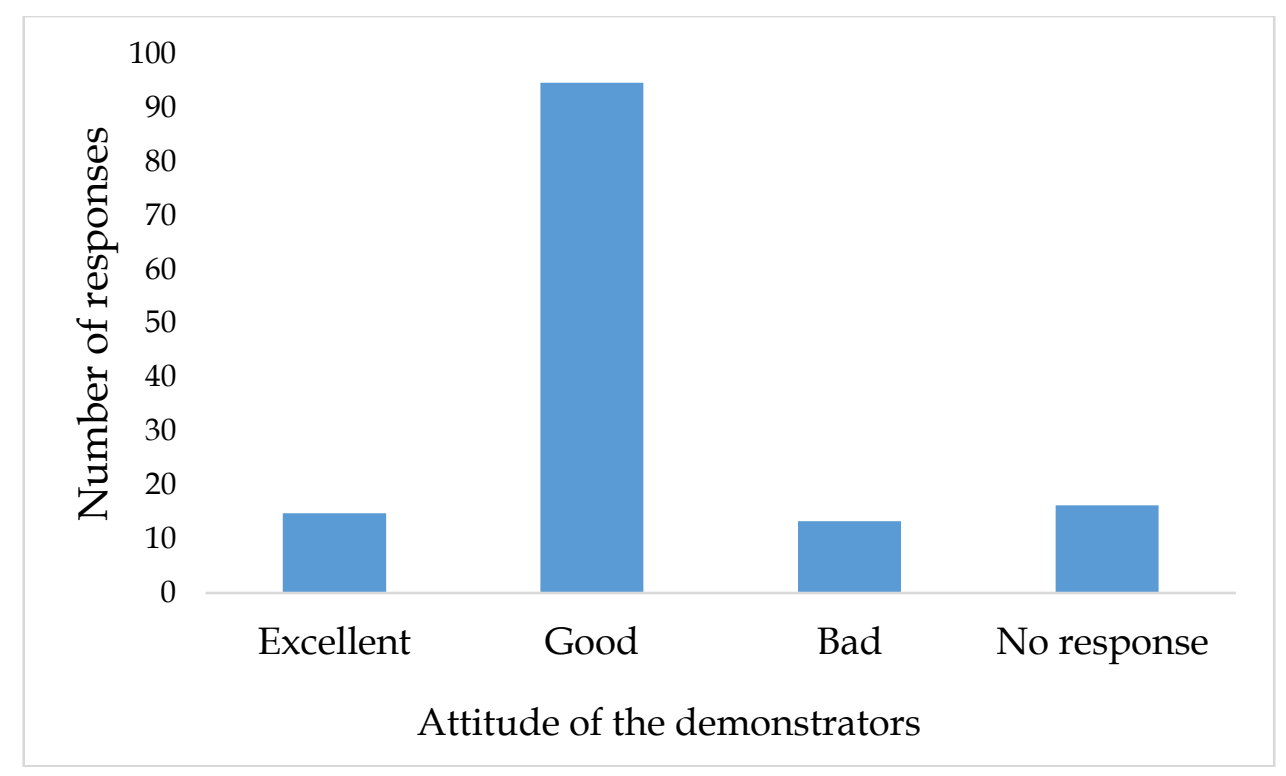

Figure 5. Responses to the overall attitudes of the demonstrators.

The majority of the participants $(69.0 \%)$ did not want the services of the demonstrators with regards to them assisting in practical sessions to be terminated while only $16.0 \%$ of the participants felt that the services of the demonstrators could be terminated with $15.0 \%$ of the participants not responding to whether the services of the demonstrators during practical sessions could be terminated or not. The results in the present study, agree with those in He et al., (2018) where the majority (97.0\%) of the participants stated that they strongly agreed that the continued use of the teaching assistants could be beneficial.

Figure 6 shows that only $36.0 \%$ of the participants, responded that the number of demonstrators allocated to the practical sessions should be increased compared to $53.0 \%$ of the participants who felt that the number of the demonstrators was adequate and did not need to be increased while $11.0 \%$ of the participants did not indicate whether there was a need or no need of the number of demonstrators to be increased.

More $(69.0 \%)$ participants mentioned that they wished they could also become demonstrators when they became seniors compared to only $24.0 \%$ of them indicating that they do not wish to become demonstrators when they are senior students whereas $13.0 \%$ of them did not indicate their preferences shown in Figure 6. The findings of the majority of the participants wanting to become demonstrators when they get to the upper levels of study are in line with the findings of He et al., (2018), where about $64.0 \%$ of the participants said that the positive contribution that the teaching assistants had made to their learning had encouraged them to want to take a similar role in their future. 


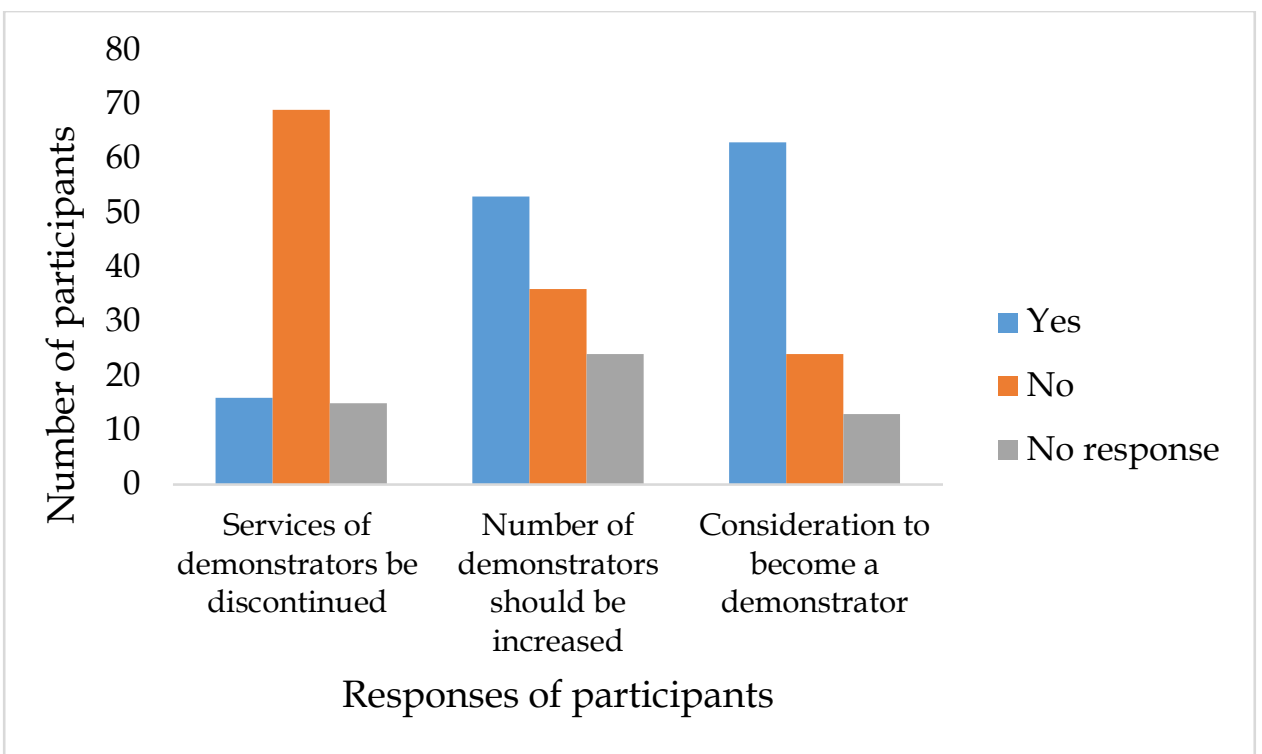

Figure 6. Responses of the participants on services of demonstrators and desire to become a demonstrator.

\section{Conclusion}

The present study assessed the experience of currently registered undergraduate Biology students on the competence and ability of either postgraduate students or senior undergraduate students that are employed as demonstrators for practical classes. From the study, it can be concluded that in most of the critical areas, there are mixed feelings on the competencies and the abilities of the demonstrators to provide the needed information for the undergraduate students. Areas such as getting prepared for classes, marking of scripts, behaviours of the demonstrators during the practical classes as regards the use of cell phones, and talking amongst themselves during the practical classes are areas where improvements are needed on the part of the demonstrators. Some of the participants sometimes doubted some of the answers that the demonstrators gave them and also felt that their marking was not accurate. However, the majority of the participants indicated that the demonstrators were approachable, helpful, and had adequate content knowledge of practical sessions and that their services should be continued. It is hence suggested that the laboratory demonstrators should be equipped with skills and guidance on how to fairly assess the students' laboratory reports, receive training on how to relate and respect the undergraduate students, and how to give feedback to them positively and constructively. The guidance and training would provide the demonstrators with more confidence, knowledge, better communication skills, and even confidence for them to teach and have a passion to pursue a teaching career. It is also suggested that the demonstrators have weekly classes on what will be discussed in the practical sessions and write pre-practical tests before they assist the undergraduate students with the practical sessions to improve their competency in marking and giving accurate answers during the practical sessions. 


\section{Acknowledgments}

The authors would sincerely like to thank all the students who completed the questionnaires and participated in the study.

\section{References}

Basey, J. M., Maines, A. P., \& Francis, C. D. (2014). Time efficiency, written feedback, and student achievement in inquiry-oriented Biology labs. International Journal for the Scholarship of Teaching and Learning, 8(2). http://doi.org/10.20429/ijsotl.2014.080215

Bangera, G., \& Brownell, S. E. (2014). Course-based undergraduate research experiences can make scientific research more inclusive. CBE-Life Sciences Education, 13(4), 602606. Retrieved from https://www.lifescied.org/doi/pdf/10.1187/cbe.14-06-0099

Bowling, B., Doyle, M., Taylor, J., \& Antes, A. (2015). Professionalizing the role of peer leaders in STEM. Journal of STEM Education: Innovations and Research, 16(2), 30.

Braun, M., \& Kirkup, L. (2016). Non-physics peer demonstrators in undergraduate laboratories: a study of students' perceptions. European Journal of Physics, 37. http://doi.org/10.1088/0143-0807/37/1/015703

Brauna, M., Kirkupabc, L., \& Chadwicka, S. (2018). The impact of inquiry orientation and other elements of cultural framework on student engagement in first year laboratory programs. International Journal of Innovation in Science and Mathematics Education, 26(4), 30-48.

Buerkel-Rothfuss, N. L., \& Fink, D. S. (1993). Student perceptions of teaching assistants (TAs). Basic Communication Course Annual, 5(8). Retrieved from https://ecommons.udayton.edu/bcca/vol5/iss1/8

Carlson, K., Turvold Celotta, D., Curran, E., Marcus, M., \& Loe, M. (2016). Assessing the impact of a multi-disciplinary peer-led-team learning program on undergraduate STEM education. Journal of University Teaching \& Learning Practice, 13(1).

Chapin, H. C., Wiggins, B. L., \& Martin-Morris, L. E. (2014). Undergraduate science learners show comparable outcomes whether taught by undergraduate or graduate teaching assistants. Research and Teaching, 44(2), 90-99.

Chiu, P. H. P., \& Corrigan, A. P. (2019). A study of graduate teaching assistants' selfefficacy in teaching: Fits and starts in the first Triennium of teaching. Cogent Education, 6:1. https://doi.org/10.1080/2331186X.2019.1579964

DeBeck, G., \& Demaree, D. (2012). Teaching assistant-student interactions in a modified SCALE-UP classroom. Paper presented at the 2011 Physics Education Research Conference (1413, pp. 167-170). Omaha, Nebraska, 3-4 August 2011.

Drane, D., Micari, M., \& Light, G. (2014): Students as teachers: Effectiveness of a peer-led STEM learning programme over 10 years. Educational research and evaluation An International Journal on Theory and Practice, 20(3), 210-230. http://doi.org/10.1080/13803611.2014.895388

Durán, C. E. P., Bahena, E. N., Rodríguez, M. de los Á. G., Baca, G. J., Uresti, A. S., Elizondo-Omaña, R. E., \& López, S. G. (2012). Near-peer teaching in an anatomy course with a low faculty-to-student ratio. Anatomy Science Education, 5, 171-176. http://doi.org/10.1002/ase.1269

Felege, C. J. (2018). The long-Term Significance of working as an undergraduate teaching assistant. Theses and Dissertations, 2209. Retrieved from https://commons.und.edu/theses/2209

Fernald, P., Chiseri, M., Lawsom, D., Scroggs, G., \& Riddell, J. (1975). Systematic manipulation of student pacing, the perfection requirement, and contact with a teaching assistant in an introductory psychology course. Teaching of Psychology, 2, 147-151. http://doi.org/10.1207/s15328023top0204_1 
Filz, T., \& Gurung, R. A. R. (2013). Student perceptions of undergraduate teaching $\begin{array}{llll}\text { assistants. } & \text { Teaching } & \text { of } & \text { Psychology, }\end{array}$ http:/ / doi.org/10.1177/0098628312465864

Flaherty, A., O’Dwyer, Mannix-McNamara, P., \& Leahy, J. J. (2017). Aligning perceptions of laboratory demonstrators' responsibilities to inform the design of a laboratory teacher development program. Journal of Chemical Education, 94, 1007-1018. http:/ / doi.org/10.1021/acs.jchemed.7b00210

French, D., \& Russell, C. (2002). Do graduate teaching assistants benefit from teaching inquiry-based laboratories? Bioscience, 52(11), 1036-1041. https://doi.org/10.1641/0006-3568(2002)052[1036:DGTABF]2.0.CO;2

Gardner, G. E., \& Jones, M. G. (2011). Pedagogical preparation of the science graduate teaching assistant: Challenges and implications. Fall, 20(2).

Graham, M. J., Frederick, J., Byars-Winston, A., Hunter, A.-B., \& Handelsman, J. (2013). Increasing persistence of college students in STEM. Science, 341(6153), 1455-1456.

Gudyanga, R., \& Jita, L. (2019). Teachers' implementation of laboratory practicals in the South African physical sciences curriculum. Issues in Educational Research, 29(3).

He, K. D., B S, W. T. L., \& Zhang G. A. (2018). Program of medical students as teaching assistants in an Anatomy course: Effectiveness and improvement. Austin Journal of Anatomy, 5(2), 1081.

Hofstein, A., \& Lunetta, V. N. (2004). The laboratory in science education: foundations for the twenty-first Century. Science Education, 88(1), 28-54. https://doi.org/10.1002/sce.10106

Kendall, K. D., \& Schussler, E. E. (2013). Evolving impressions: Undergraduate perceptions of graduate teaching assistants and faculty members over a semester. Life Sciences, 12, 92-105. https://doi.org/10.1187/cbe.12-07-0110

Kendall, K. D., \& Schussler, E. E. (2012). Does instructor type matter? Undergraduate student perception of graduate teaching assistants and professors. CBE-Life Sciences Education, 11(2), 187-199.

Kirkup, L., Varadharajan, M., \& Braun, M. (2016). A Comparison of student and demonstrator perceptions of laboratory-based, inquiry-oriented learning experiences. International Journal of Innovation in Science and Mathematics Education, 24(2), 1-13.

Lachman, N., Christensen, K. N., \& Pawlina, W., (2013). Anatomy teaching assistants: Facilitating teaching skills for medical students through apprenticeship and mentoring. Medical Teacher, 35, e919-e925. https:// doi.org/10.3109/0142159X.2012.714880

Lama, T., \& Joullie, J. (2015). Casualization of academics in the Australian higher education: Is teaching quality at risk? Research in Higher Education, 28, 1-11.

Linn, M. C., Palmer, E., Baranger, A., Gerard, E., \& Stone, E. (2015). Undergraduate research experiences: Impacts and opportunities. Science, 347. https://doi.org/10.1126/science.1261757.

McKeegan, P. (1998). Using undergraduate teaching assistants in a research methodology course. Teaching of Psychology, 25, 11-14. https://doi.org/10.1207/s15328023top2501_4

Meyer, K. R., \& Mao, Y. (2014). Comparing student perceptions of the classroom by U.S. American and International teaching assistants. Higher Learning Research Communication, 4(3), 12-22. https://doi.org/10.18870/hlrc.v4i3.206

Patitsas, E. (2012). A case study of environmental factors influencing teaching assistant job satisfaction. In Proceedings of the ninth annual international conference on International computing education research (ICER '12), (pp. 11-16). Association 
for Computing Machinery, New York, NY, USA. https:// doi.org/10.1145/2361276.2361280

Philipp, S. B., Tretter, T. R., \& Rich, C. V. (2016a). Development of undergraduate teaching assistants as effective instructors in STEM courses. Journal of College Science Teaching, 45(3), 74-82.

Philipp, S. B., Tretter, T. R., \& Rich, C. V. (2016b). Undergraduate teaching assistant impact on student academic achievement. Electronic Journal of Science Education, 20(2).

Russell, C. B., \& Weaver, G. C. (2008). Student perceptions of the purpose and function of the laboratory in science: A grounded theory study. International Journal for the Scholarship of Teaching and Learning, 2(2). http://doi.org/10.20429/ijsotl.2008.020209

Schussler, E. E., Read, Q., Marbach-Ad, G., Miller, K., \& Ferzli, M. (2015). Preparing Biology graduate teaching assistants for their roles as instructors: An assessment of institutional approaches. CBE-Life Sciences Education, 21, 14(3). http://doi.org/10.1187/cbe.14-11-0196

Sana, F., Pachai, M. V., \& Kim, J. A. (2011). Training undergraduate teaching assistants in a peer mentor course. Transformative dialogues: Teaching $\mathcal{E}$ Learning Journal, 4(3).

Spike, B. T. (2014). An investigation of the knowledge, beliefs, and practices of Physics teaching assistants [Graduate Thesis]. University of Colorado.

Spike, B. T. (2016). Design and application of a framework for examining the beliefs and practices of physics teaching assistants. Physical Review Physics Education Research, 12. http:// doi.org/10.1103/PhysRevPhysEducRes.12.010114

Tulane, S., \& Beckert, T. E. (2011). Perceived utility and knowledge of graduate teaching assistants. Journal of the Scholarship of Teaching and Learning, 11(4), $44-55$.

Weidert, J. M., Wendorf, A. R., Gurung, R. A., \& Filz, T. (2012). A survey of graduate and undergraduate teaching assistants. College teaching, 60(3), 95-103. http://doi.org/10.1080/87567555.2011.637250

Wheeler, L. B., Maeng, J. L., \& Whitworth, B. A. (2015). Teaching assistants' perceptions of a training to support an inquiry-based general chemistry laboratory course. Chemistry Education Research and Practice, 16(4), 824-842. http://doi.org/10.1039/c5rp00104h

Wilson, Z. S., Holmes, L., deGravelles, K., Sylvain, M. R., Batiste, L., Johnson, M., McGuire, S. Y., Pang, S. S., \& Warner, I. M. (2011). Hierarchical mentoring: A transformative strategy for improving diversity and retention in undergraduate STEM disciplines. Journal of Science Education and Technology, 21, 148-156. http://doi.org/10.1007/s10956-011-9292-5

Wyse, D., Fentiman, A., Sugrue, C., \& Moon, S. (2014). English language teaching and whole school professional development in Tanzania. International Journal of Educational Development, 38, 59-68. http://doi.org/10.1016/j.ijedudev.2014.04.002 
Appendix 1

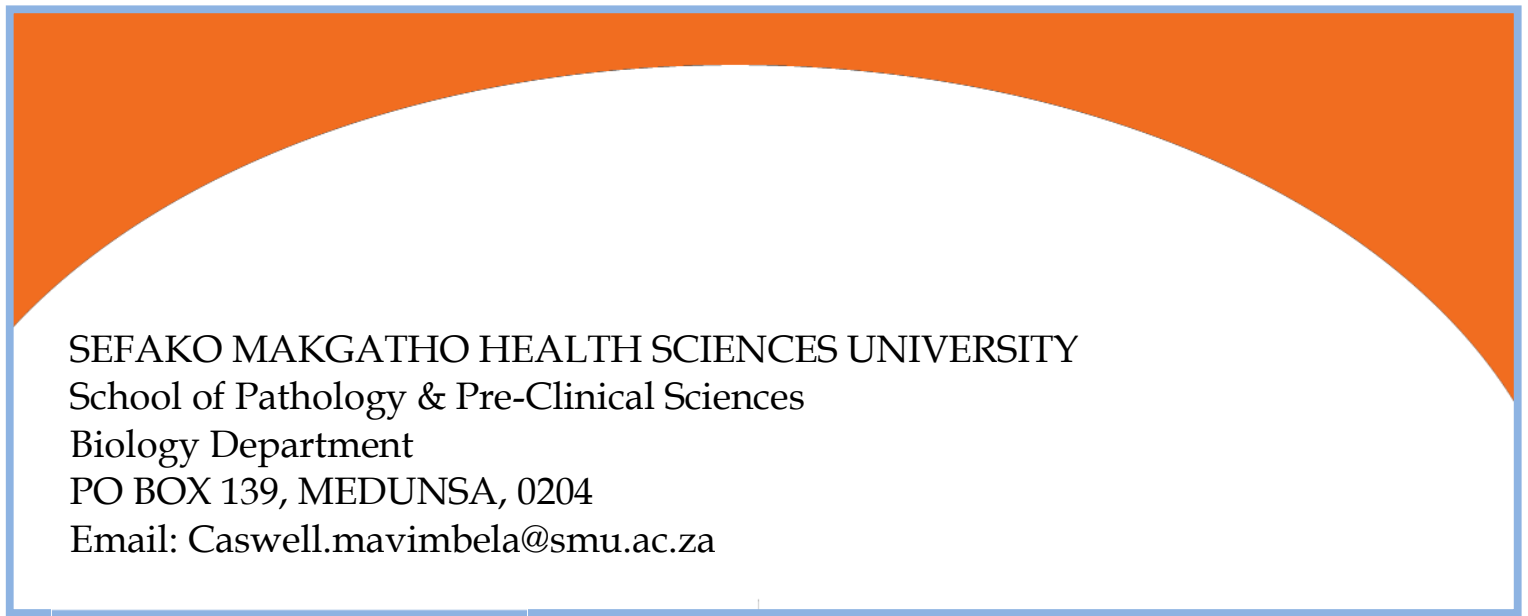

SEFAKO MAKGATHO HEALTH SCIENCES UNIVERSITY

School of Pathology \& Pre-Clinical Sciences

Biology Department

BOX 139, MEDUNSA, 0204

Email: Caswell.mavimbela@smu.ac.za

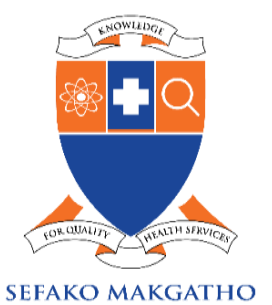

HEALTH SCIENCES UNIVERSITY

Perceptions of Students towards the Postgraduate Biology Practical Demonstrators at Sefako Makgatho Health Sciences University, Pretoria, South Africa

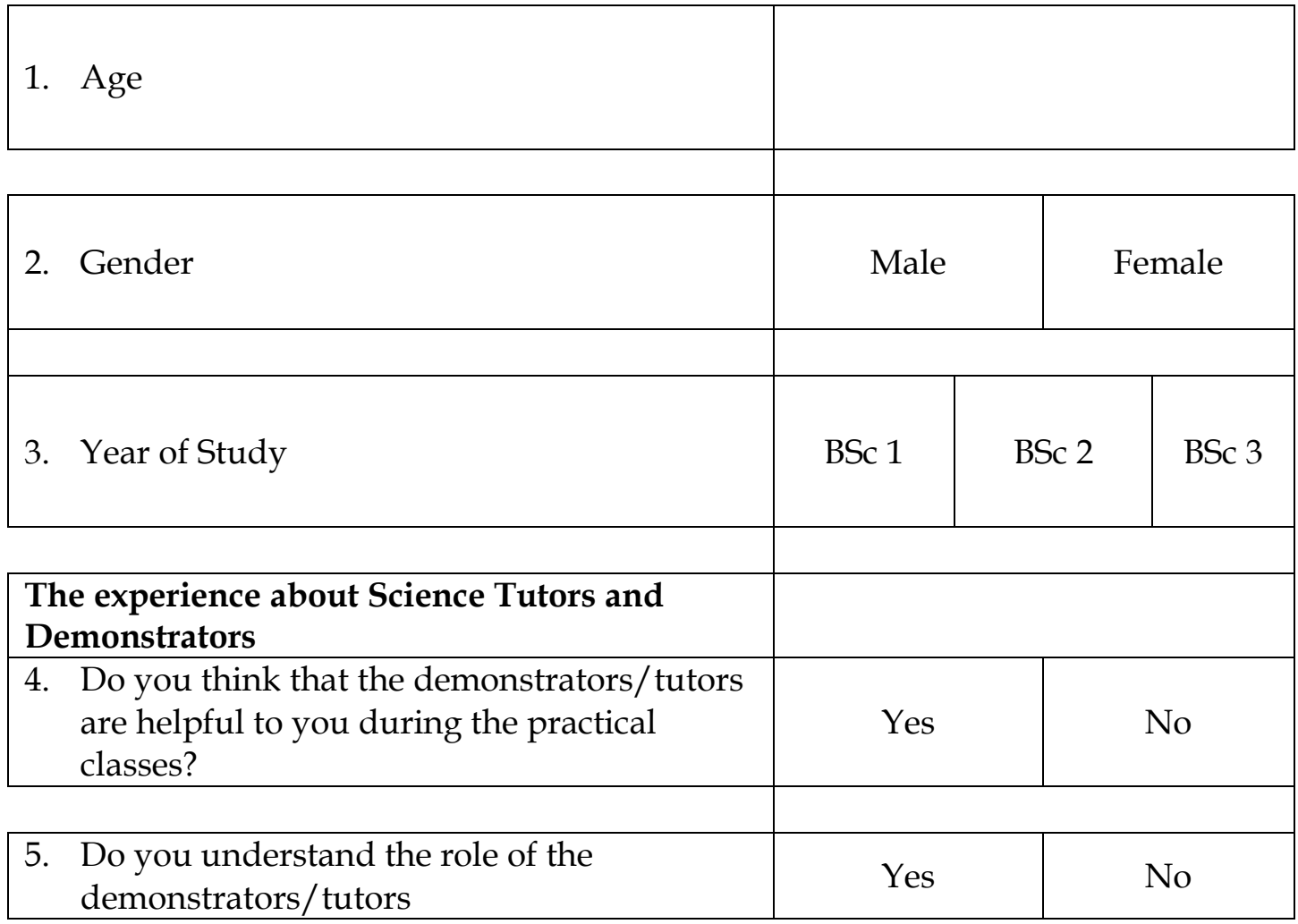




\begin{tabular}{|c|c|c|}
\hline $\begin{array}{l}\text { 6. Do you have a problem like taking } \\
\text { instructions from them? }\end{array}$ & Yes & No \\
\hline $\begin{array}{l}\text { 7. Do you think demonstrators/tutors/ tutors } \\
\text { have enough knowledge of the content of } \\
\text { the practicals/tutorials? }\end{array}$ & Yes & No \\
\hline $\begin{array}{l}\text { 8. Do you feel like they are well prepared for } \\
\text { practicals/tutorials? }\end{array}$ & Yes & No \\
\hline $\begin{array}{l}\text { 9. Do you ever doubt their responses or } \\
\text { knowledge on some aspects of } \\
\text { practicals/tutorials? }\end{array}$ & Yes & No \\
\hline $\begin{array}{l}\text { 10. Do you think that they are qualified to mark } \\
\text { your scripts? }\end{array}$ & Yes & No \\
\hline $\begin{array}{l}\text { 11. Do you think they mark your scripts } \\
\text { accurately? }\end{array}$ & Yes & No \\
\hline $\begin{array}{l}\text { 12. Have you ever complained about their } \\
\text { marking being inaccurate? }\end{array}$ & Yes & No \\
\hline $\begin{array}{l}\text { 13. If you have a query are they willing to listen } \\
\text { to your complaint? }\end{array}$ & Yes & No \\
\hline $\begin{array}{l}\text { 14. Do you feel that the demonstrators/tutors } \\
\text { are fair and do not have favourites when } \\
\text { they mark/assist in practicals/tutorials? }\end{array}$ & Yes & No \\
\hline $\begin{array}{l}\text { 15. Do you believe that the } \\
\text { demonstrators/tutors have the final say in } \\
\text { cases of you not being happy with the way } \\
\text { they have marked your scripts? }\end{array}$ & Yes & No \\
\hline 16. If No who do you feel has the final say? & Lecturer & $\begin{array}{c}\text { Technical } \\
\text { officer }\end{array}$ \\
\hline $\begin{array}{l}\text { 17. Is it easy for you to approach } \\
\text { demonstrators/tutors if you have queries? }\end{array}$ & Yes & No \\
\hline $\begin{array}{l}\text { 18. Do you think they are impossible to deal } \\
\text { with? }\end{array}$ & & \\
\hline $\begin{array}{l}\text { 19. If a demonstrator mistreated you would you } \\
\text { report them to the members of staff? }\end{array}$ & Yes & No \\
\hline
\end{tabular}




\begin{tabular}{|c|c|c|}
\hline $\begin{array}{l}\text { 20. How would you rate their attitudes towards } \\
\text { you }\end{array}$ & Excellent & Bad \\
\hline $\begin{array}{l}\text { 21. Do you think they talk too much among } \\
\text { themselves and not pay attention to you? }\end{array}$ & Yes & No \\
\hline $\begin{array}{l}\text { 22. Have you ever noticed them using their cell } \\
\text { phones when they were supposed to be } \\
\text { helping you? }\end{array}$ & Yes & No \\
\hline $\begin{array}{l}\text { 23. Would you recommend that we increase the } \\
\text { numbers of demonstrators/tutors in your } \\
\text { class? }\end{array}$ & Yes & No \\
\hline $\begin{array}{l}\text { 24. Would you recommend that we do away } \\
\text { with the use of demonstrators/tutors? }\end{array}$ & Yes & No \\
\hline $\begin{array}{l}\text { 25. Can you provide an area where you think } \\
\text { they should improve? }\end{array}$ & Yes & No \\
\hline $\begin{array}{l}\text { 26. Would you also apply to become a } \\
\text { demonstrator/tutor when you reach a } \\
\text { senior level? }\end{array}$ & Yes & No \\
\hline $\begin{array}{l}\text { 27. Which level of students do you feel should } \\
\text { be allowed to demonstrate? }\end{array}$ & Post-graduate & $\begin{array}{c}\text { Any senior } \\
\text { level }\end{array}$ \\
\hline
\end{tabular}

